\title{
Ten-year Growth Response to Fertilizer of a 90-year-old Black Spruce Stand in Northwestern Ontario
}

\author{
I. K. Morrison', H. S. D. Swan² \\ N. W. Foster' and D. A. Winston'
}

\begin{abstract}
${ }^{1}$ Department of the Environment, Canadian Forestry Service, Great Lakes Forest Research Centre, Sault Ste. Marie, Ontario. P6A 5M7

${ }^{2}$ Formerly with the Pulp and Paper Research Institute of Canada, 570 St. John's Blvd., Pointe Claire, Quebec. Present address: Canadian Pulp and Paper Association, Woodlands Section, 2300 Sun Life Building, Montreal, Quebec. H3B 2X9
\end{abstract}

\begin{abstract}
A fertilizer experiment with three levels of urea, two of triple superphosphate and two of muriate of potash was established in a 90-year-old black spruce (Picea mariana [Mill.] B.S.P.] stand on a moist-to-wet site in northwestern Ontario. Response variables estimated or measured at 6 and 10 years after fertilization were mean DBH increment, BA increment (per cent and absolute), and total and merchantable volume increment. Analysis of variance and Duncan's New Multiple Range Test were carried out. Results indicated significant growth response only for one combination of $\mathrm{N}$ and $\mathrm{P}$, and only in relation to mean DBH increment. No interactions were significant. Inspection of data revealed trends suggesting that response, which was limited, was generally to $P$ and to a smaller degree to N. Compared with literature values, volume growth responses were generally low, about $9 \mathrm{~m}^{3} /$ ha estimated total volume increment over controls in 10 years. Possible reasons for low response, including nutrient loss (particularly of $N$ ) from the root zone and low application rates are discussed.
\end{abstract}

\section{Résumé}

L'auteur décrit une expérience faite avec un fertilisant contenant trois concentrations d'urée, deux de triple superphosphate et deux de muriate de potasse dans un peuplement d'Epinette noire (Picea mariana [Mill.] B.S.P.) âgé de 90 ans, dans une station humide ou mouillée située dans le nord-ouest de l'Ontario. Les variables de la réaction évaluées ou mesurées 6 et 10 ans après la fertilisation furent l'augmentation du d.h.p. moyen, l'accroissement de la ST (surface terrière), en pourcentage et en chiffres absolus, et l'augmentation du volume total et marchand. Une analyse de variance ainsi que le "Duncan's New Multiple Range Test" furent entrepris. Les résultats indiquèrent une réaction de croissance significative seulement pour une combinaison de $\mathrm{N}$ et $\mathrm{P}$, et seulement relativement à l'augmentation du d.h.p. moyen. Aucune interaction ne fut significative. L'examen des données révéla des tendances indiquant que la réaction, laquelle fut limitée, favorisait habituellement le $\mathrm{P}$ et, à un degré moindre, le $\mathrm{N}$. Comparativement aux données déjà rapportées, les réactions de croissance en volume sur une période de 10 ans furent généralement basses (on a évalué l'augmentation totale en volume à $9 \mathrm{~m}^{3} / \mathrm{ha}$ de plus que chez les arbres témoins). L'auteur étudie les raisons possibles d'une réaction aussi minime, y compris la perte en matières nutritives (en particulier de $\mathrm{N}$ ) dans la zone racinaire, puis, les taux peu élevés d'application du fertilisant.

\section{Introduction}

The experiment described in this paper originated in 1964, as the offspring of an agreement between Great Lakes Paper Company Limited of Thunder Bay, Ontario and the Pulp and Paper Research Institute of Canada, and was one in a series of experiments in a cooperative program of forest fertilization research. Under the agreement, industry undertook to carry out all field work and the Institute all analyses. In late 1971 the Institute's responsibilities were transferred to the Canadian Forestry Service.

At the time this experiment was established there was very little information on response of semimature black spruce (Picea mariana [Mill.] B.S.P.) stands to mineral fertilizers. According to Armson's (1967) compilation, there were only two trials established before 1964 in semimature natural black spruce forest in eastern Canada. Even now little information on response of semimature black spruce forest to mineral fertilizers has been published. One early exception, however, involved black spruce growing under raised-bog conditions in northern Minnesota where, in terms of leader growth, marked responses were reported to nitrogen $(\mathrm{N})$ and phosphorus (P) fertilizers singly and in combination (Watt 1966).

The following experiment was designed to determine long-term growth responses of semimature black spruce forest on a moist site in northwestern Ontario to various combinations of $\mathrm{N}, \mathrm{P}$ and $\mathrm{K}$ supplied as urea, triple superphosphate and muriate of potash.

\section{Study area}

The study area is located (lat. $48^{\circ} 43^{\prime} \mathrm{N}$; long. $90^{\circ} 07^{\prime} \mathrm{W}$ ) on the limits of the Great Lakes Paper Company Limited, some $9 \mathrm{~km}$ directly north of Lower Shebandowan Lake, and some $70 \mathrm{~km}$ WNW of Thunder Bay, Ontario. It is within the Upper English River Section (B.11) of the Boreal Forest Region (Rowe 1972). The overall climate is modified-continental and falls within the Rainy RiverThunder Bay Climatic Region of Chapman and Thomas (1968). The average length of growing season is approximately 160 days, extending from May though September inclusive (ibid.). Mean annual total precipitation, as measured at the nearest weather station (Kakabeka Falls, Ontario), is $720 \mathrm{~mm}$, with approximately $56 \%$ of this falling during the growing season (Anon. 1973). Potential evapotranspiration was estimated at $51 \mathrm{~cm}$ annually (Chapman and Thomas 1968).

The experiment is located on the boundary of the Savanne Site District of Site Region 3W-Lake Nipigon, and the Quetico Site District of Site Region 4W-Pigeon River (Hills 1959). The site is 
heterogeneous with regard to moisture, because of a variable-depth, perched water table deriving from prominent bands of compacted fine sand which occurred at a depth of $50 \mathrm{~cm}$ in drier areas and much closer to the surface in wetter areas. In wetter areas water stood on the surface in the lower pits and channels during the early summer. In drier areas (in one of which was located the pit from which the samples for analyses were taken) the soil profile is characteristic of an Orthic HumoFerric Podzol (Anon. 1974), whereas in wetter areas, typified by high chroma mottling, it would be classed as Gleyed Humo-Ferric Podzol. Mineral soil texture (Table 1) is sandy loam over sand. Concentrations of total $\mathrm{N}$ and available $\mathrm{P}$ were low, though not unusually so. Levels of exchangeable cations were comparable with usual literature values.

The experiment was established in 1964 in a fully stocked, relatively pure stand approximately 90 years old. Mean height, diameter at breast height $(\mathrm{DBH})$ and basal area (BA) were $14.8 \mathrm{~m}$, $14.8 \mathrm{~cm}$, and $34 \mathrm{~m}^{2} /$ ha, respectively. The forest floor was occupied by a continuous moss layer with Sphagnum spp. and Pleurozium schreberi (BSG.) Mitt. predominating, and Hypnum cristacastrensis Hedw. and Hylocomium splendens (Hedw.) BSG. in lesser abundance. Herbs and shrubs that were relatively common included Equisetum sylvaticum L., Lycopodium annotinum L., Cornus canadensis L., Gaultheria hispidula (L.) Bigel., Ledum groenlandicum Oeder, Smilacina trifolia (L.) Desf., and Petasites palmatus (Ait.) Grey.

\section{Methods}

A completely randomized three-factor factorial experiment, with three levels of $\mathrm{N}(\mathrm{O}, 112,224 \mathrm{~kg}$ $\mathrm{N} /$ ha) supplied as urea, two levels of $\mathrm{P}(\mathrm{O}, 25 \mathrm{~kg}$ $\mathrm{P} / \mathrm{ha}$ ) supplied as triple superphosphate, and two levels of $\mathrm{K}(\mathrm{O}, 93 \mathrm{~kg} \mathrm{~K} / \mathrm{ha})$ supplied as muriate of potash, for a total of 12 treatments replicated three times for a total of 36 measurement plots was established in 90-year-old black spruce forest in October, 1964. Measurement plots were circular, 0.0182 ha in area, with buffer zones approximately $10 \mathrm{~m}$ wide. Trees were identified in the field by numbered metal tags. Stems were rubbed to remove scaly bark and the breast-height position was marked with paint. Fertilizers in amounts appropriate to the experimental design were hand-broadcast on the soil surface the following May, at the beginning of the 1965 growing season. Initial DBH measurement to the nearest $0.025 \mathrm{~cm}$ was made by steel diameter tape in October, 1964. Through an oversight only 30 trees were measured on each plot at that time, precluding an accurate estimate of initial BA, total volume or merchantable volume. This was rectified in the fall of 1968 when the additional trees were identified and measured. Final remeasurement of DBH, also by steel diameter tape to the nearest 0.025 cm, was done in September, 1974. In accordance with standard procedure trees that died during the period 1964-1974 were deleted from the tally. All measurements were in English units with subsequent conversion to S.I. units.

The mean DBH increment estimate was based on DBH growth of originally measured trees only. Per cent BA increments of originals (1964 to 1974) and all trees (1969 to 1974) were derived from appropriate differences in sums of individual-tree BAs. Measured total and merchantable volume increments (1969 to 1974) were estimated in the following manner. A regression of height-on-diameter was derived from observations on 180 sample trees. This regression was used to estimate the height of each tree. From the estimated heights and measured DBHs, total and merchantable volumes, both for 1969 and 1973, were computed on a tree-by-tree basis for each plot using Honer's (1967) volume equations. Thus, change in tree form due to treatment was not considered. Increments of total and merchantable volume were calculated by subtracting 1964 values from remeasurement values. These various data were subjected to analyses of variance and Duncan's New Multiple Range Test for the detection of significant differences among means.

In order to obtain working data, it seemed desirable to produce estimates of 10-year increments of BA, and total and merchantable volume. This was done as follows. First, for BA, per cent BA increases (1964-1974) were calculated on the basis of growth of original trees only. These per-

Table 1. Soil physical and chemical properties

\begin{tabular}{|c|c|c|c|c|c|c|c|c|c|c|c|c|}
\hline \multirow[b]{2}{*}{ Horizon } & \multirow[b]{2}{*}{$\begin{array}{r}\text { Depth } \\
(\mathbf{c m})\end{array}$} & \multicolumn{3}{|c|}{ Texture $^{1}(\%)$} & \multirow[b]{2}{*}{$\mathrm{pH}^{2}$} & \multirow[b]{2}{*}{ O.M. } & \multirow{2}{*}{$\begin{array}{c}\text { Total } \\
\mathbf{N} \\
(\%)\end{array}$} & \multirow{2}{*}{$\underset{\text { Pvail.4 }}{\text { Ppm) }}$} & \multicolumn{3}{|c|}{ Exchangeable $^{5}$} & \multirow[b]{2}{*}{$\begin{array}{c}\text { C.E.C. }{ }^{5} \\
(\mathrm{meq} / 100 \mathrm{~g}\end{array}$} \\
\hline & & $\mathbf{S}$ & $\mathbf{S i}$ & C1 & & & & & $\mathbf{K}$ & $\underset{\mathrm{eq} / 100}{\mathrm{Ca}}$ & Mg & \\
\hline 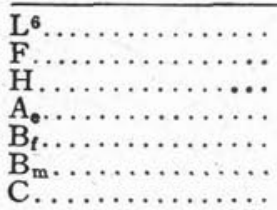 & $\begin{array}{r}0-9 \\
9-20 \\
20-22 \\
22-24 \\
24-37 \\
37-59 \\
>59\end{array}$ & $\begin{array}{l}- \\
\overline{7} \\
71 \\
68 \\
68 \\
93\end{array}$ & $\begin{array}{l}\overline{-} \\
\overline{2} \\
26 \\
30 \\
06\end{array}$ & $\begin{array}{l}- \\
- \\
3 \\
3 \\
2 \\
1\end{array}$ & $\begin{array}{l}4.4 \\
3.6 \\
4.0 \\
3.6 \\
4.6 \\
5.6 \\
5.5\end{array}$ & $\begin{array}{r}82.4 \\
68.2 \\
28.4 \\
12.2 \\
3.0 \\
1.2 \\
0.9\end{array}$ & $\begin{array}{l}0.92 \\
0.94 \\
0.42 \\
0.15 \\
0.08 \\
0.04 \\
0.03\end{array}$ & $\begin{array}{r}104.0 \\
29.3 \\
16.7 \\
2.5 \\
3.4 \\
1.9 \\
3.0\end{array}$ & $\begin{array}{l}6.85 \\
2.30 \\
0.49 \\
0.13 \\
0.08 \\
0.10 \\
0.01\end{array}$ & $\begin{array}{r}19.86 \\
13.12 \\
6.14 \\
0.65 \\
0.67 \\
0.92 \\
0.80\end{array}$ & $\begin{array}{l}4.52 \\
3.70 \\
2.71 \\
0.25 \\
0.08 \\
0.29 \\
0.04\end{array}$ & $\begin{array}{l}62.5 \\
93.4 \\
43.3 \\
21.2 \\
11.4 \\
27.1 \\
18.2\end{array}$ \\
\hline
\end{tabular}

${ }^{1 B}$ Boyoucos hydrometer procedure. 
centages were used to discount 1974 plot total BAs to 1964 values. Increments were obtained by difference. Estimates of 10 -year total and merchantable volume increment were obtained in a like manner. As they were extrapolated, these data were not subjected to statistical analyses.

\section{Results}

Data pertaining to mean $\mathrm{DBH}$ increase are presented in Table 2 . In relation to this parameter, treatment N112 P25 resulted in a significant (at the $5 \%$ level) increase in $\mathrm{DBH}$ growth over control. Diameter growth of controls was slower than under any other treatment. No interaction proved significant. Data pertaining to BA are presented in Table 3 . Analyses of variance revealed no significant differences in per cent BA increase of either original trees only (1964 to 1974) or all trees (1969 to 1974). No interactions were significant. In terms of ranking, three treatments grew slower than controls; generally, the greater BA increments could be identified with $P$.

In relation to both total and merchantable volume increment (1969 to 1974), analyses of variance (Table 4 ) revealed significant differences related

Table 2. Mean DBH increment (cm.) with standard deviation by treatment for 10-year period 1964-1974, based on surviving original trees

\begin{tabular}{|c|c|c|}
\hline Treatment & $\begin{array}{c}\text { Mean DBH } \\
\text { increment } \\
(\mathrm{cm})\end{array}$ & $\begin{array}{l}\text { Standard } \\
\text { deviation } \\
\quad(\mathrm{cm})\end{array}$ \\
\hline 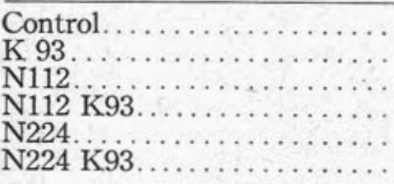 & $\begin{array}{r}.87 \\
.98 \\
1.12 \\
.94 \\
1.11 \\
1.04\end{array}$ & $\begin{array}{l}.05 \\
.09 \\
.28 \\
.22 \\
.38 \\
.12\end{array}$ \\
\hline 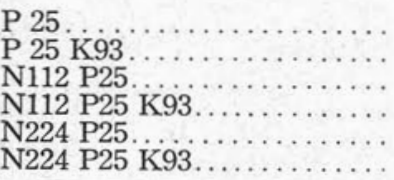 & $\begin{array}{l}1.08 \\
1.06 \\
1.28 * \\
1.16 \\
1.20 \\
1.00\end{array}$ & $\begin{array}{l}.14 \\
.20 \\
.16 \\
.21 \\
.03 \\
.05\end{array}$ \\
\hline
\end{tabular}

*Significantly different from Control at $5 \%$ confidence level.

Table 3. Basal area growth $(\%)$ of original trees for full 10 -year period, and of all trees for last 6 years, and estimated basal area increment $\left(\mathrm{m}^{2} / \mathrm{ha}\right)$ for full 10-year period

\begin{tabular}{|c|c|c|c|}
\hline \multirow[b]{2}{*}{ Treatment } & \multicolumn{2}{|c|}{ Basal area growth } & \multirow[b]{2}{*}{$\begin{array}{c}\text { Estimated basal } \\
\text { area increment } \\
1964-1974 \\
\left(\mathrm{~m}^{2} / \mathrm{ha}\right)\end{array}$} \\
\hline & $\begin{array}{c}\text { Originals } \\
1964-1974 \\
(\%)\end{array}$ & $\begin{array}{c}\text { Al1 trees } \\
1969-1974 \\
(\%)\end{array}$ & \\
\hline $\begin{array}{l}\text { Control........ } \\
\text { K } 93 \ldots \ldots \ldots \ldots \\
\text { N112 } \ldots \ldots \ldots \\
\text { N112 K93.... } \\
\text { N224 } \ldots \ldots \ldots \\
\text { N224 K93..... }\end{array}$ & $\begin{array}{l}11.82 \\
12.91 \\
15.01 \\
13.70 \\
15.06 \\
14.68\end{array}$ & $\begin{array}{l}5.77 \\
6.64 \\
7.02 \\
6.08 \\
7.15 \\
6.14\end{array}$ & $\begin{array}{l}4.80 \\
3.97 \\
3.49 \\
4.83 \\
5.79 \\
4.72\end{array}$ \\
\hline $\begin{array}{l}\mathrm{P} 25 \ldots \ldots \\
\mathrm{P} 25 \\
\mathrm{~N} 112\end{array}$ & $\begin{array}{l}15.48 \\
14.52 \\
18.33 \\
16.93 \\
17.21 \\
14.11\end{array}$ & $\begin{array}{l}7.17 \\
7.17 \\
8.56 \\
7.68 \\
7.91 \\
6.72\end{array}$ & $\begin{array}{l}5.64 \\
5.09 \\
6.02 \\
4.85 \\
6.02 \\
6.05\end{array}$ \\
\hline
\end{tabular}

to P. No treatment, however, proved significantly different from the control which ranked, in this case, sixth lowest out of twelve. No interactions were significant. In estimated 10-year growth (Table 4) the best treatment produced $9 \mathrm{~m}^{3} / \mathrm{ha}$ in terms of total volume, and $8 \mathrm{~m}^{3} / \mathrm{ha}$ in terms of merchantable volume, more than controls. In conventional timber measure this is approximately 1 cord per acre.

Table 4. Measured total and merchantable volume increment $\left(\mathrm{m}^{3} / \mathrm{ha}\right)$ for the period $1969-1974$, and estimated total and merchantable volume increment $\left(\mathrm{m}^{3} / \mathrm{ha}\right)$ for the period $1964-1974$

\begin{tabular}{|c|c|c|c|c|}
\hline \multirow[b]{2}{*}{ Treatment } & \multicolumn{2}{|c|}{$\begin{array}{l}\text { Measured vol. incr. } \\
1969-1974\end{array}$} & \multicolumn{2}{|c|}{$\begin{array}{l}\text { Estimated vol. incr. } \\
1964-1974\end{array}$} \\
\hline & $\underset{(m}{\text { Total }}$ & $\begin{array}{l}\text { Merch. } \\
\text { /ha) }\end{array}$ & $\underset{(\mathbf{m}}{\text { Total }}$ & erch. \\
\hline $\begin{array}{l}\text { Control } \\
\text { K.93 } \\
\text { N112 } \\
\text { N112 K93 } \\
\text { N224 } \\
\text { N224 K93 }\end{array}$ & $\begin{array}{l}20.02 \\
16.88 \\
14.98 \\
16.94 \\
23.74 \\
17.52\end{array}$ & $\begin{array}{l}19.63 \\
16.71 \\
14.82 \\
16.62 \\
23.42 \\
17.26\end{array}$ & $\begin{array}{l}38.17 \\
31.50 \\
27.43 \\
35.00 \\
45.67 \\
37.97\end{array}$ & $\begin{array}{l}37.00 \\
30.87 \\
26.53 \\
34.30 \\
44.47 \\
37.23\end{array}$ \\
\hline 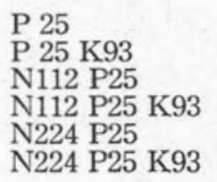 & $\begin{array}{l}22.52 \\
21.20 \\
24.16 \\
18.66 \\
23.64 \\
24.30\end{array}$ & $\begin{array}{l}22.18 \\
20.48 \\
23.83 \\
18.34 \\
23.17 \\
24.04\end{array}$ & $\begin{array}{l}44.27 \\
40.00 \\
46.80 \\
37.20 \\
46.93 \\
47.17\end{array}$ & $\begin{array}{l}42.33 \\
38.63 \\
44.93 \\
35.73 \\
44.57 \\
44.87\end{array}$ \\
\hline
\end{tabular}

\section{Discussion}

Watt and Heinselman (1965) working with natural black spruce forest on a wet organic soil in Minnesota (unlike the mineral soil of the present study) observed positive correlations between site index and foliar concentrations of $\mathrm{N}$ and $\mathrm{P}$, but not $K$, suggesting $N$ and $P$, but not $K$, deficiency. This was demonstrated to be the case in a subsequent manurial trial (Watt 1966). In the present study there is the suggestion of $\mathrm{P}$ and possibly $\mathrm{N}$ response, with virtually none to $\mathrm{K}$. It is to be stressed, however, that with the exception of mean DBH increment where N112 P25 resulted in a significant increase over controls, none of the results were statistically significant. It should be added, though, that asymmetry in stem cross-section, which tends to increase standard error, could have obscured treatment differences.

Fertilizer experiments on both black spruce wetland sites and upland mor humus sites have been uncommon. The present experiment spanned both site conditions. In a study of a 65-year-old stand in eastern Quebec, net gains over controls (i.e., extra wood) attributable to urea fertilization at a rate of $444 \mathrm{~kg} \mathrm{~N} /$ ha were reported after 5 years as nearly $8 \mathrm{~m}^{3} /$ ha (Weetman 1968) and after 10 years as over $25 \mathrm{~m}^{3} /$ ha (Weetman), proportionately more than could be accounted for by the higher dosage. Also, by way of comparison, in a study with 60-year-old black spruce in Newfoundland, Van Nostrand and Bhure (1973) reported, after only 4 years, a net gain over controls (due to urea supplied at a rate of $202 \mathrm{~kg} \mathrm{~N} / \mathrm{ha}$ ) of nearly $8 \mathrm{~m}^{3} / \mathrm{ha}$, a rate approximately equal to the 
10-year response of the present study. For jack pine (Pinus banksiana Lamb.) on sandy outwash sites in northern Ontario, responses to fertilization have been in excess of $12 \mathrm{~m}^{3} /$ ha after only 4 years (Hegyi 1974).

Comparisons involving volume increment merit mention because of the methods of estimate used in the present paper, which were necessitated by the unfortunate start to the experiment. Certainly, from a user's viewpoint, total and merchantable volume are the parameters of interest. Thorough statistical analyses of the 10-year BA and volume growth estimates were not carried out, however, because of possible imprecisions attending the estimates. The use of the 1964-1974 BA and volume growth percentages derived from original trees which were taken from each plot as estimators of overall plot growth, and subsequently used in the prediction of 1964 BA and volume, was considered reasonable, as the original trees represented on the average more than two thirds of the 1974 (and presumably 1964) standing BA. Thus, while the subsequent estimates of 10-year BA and volume increment are projected rather than measured values, they are considered useful for comparative purposes.

Questions then arise as to why there was such a poor response to fertilizer in general, and why the weak response obtained was to $P$. In relation to $\mathrm{N}$, several possibilities concerning $\mathrm{N}$-loss from the root zone exist. First, $\mathrm{pH}$ increase associated with urea hydrolysis and wetness create conditions favorable to $\mathrm{NH}_{3}$ volatilization. Second, in wet soils, readily soluble urea may diffuse rapidly beyond the reach of shallowly rooted spruce. Third, under conditions of elevated $\mathrm{pH}$ and high moisture, nitrification may occur and, subsequently, denitrification. Support for this comes from the work of Nommik and Thoren (1971) who, incubating forest humus, found considerable denitrification $\mathrm{N}$ loss. Contrary evidence, however, is found in the earlier work of Roberge and Knowles (1966), who failed to find significant nitrification in ureafertilized black spruce humus. Fourth, under soil conditions like those of the present study area, there is likely rapid immobilization of $\mathrm{N}$ by microflora.

The suggestion of $\mathrm{P}$ response, though statistically nonsignificant, is interesting, as $\mathrm{P}$ deficiency is often associated with wet-site conditions. Well known examples include $P$ deficiency of southern pines on poorly drained flatwood and soils in the southeastern United States, and of trees, particularly spruces, on P-poor peatlands in Britain. Reasons for lack of $P$ on wet sites are varied: under anaerobic conditions mycorrhizal development is usually poor; root systems are shallow and confined to the organic horizons. Here, $P$ occurs principally in organic forms (unusable by plants), and low initial content, poor aeration and cool climate all contribute to a slow rate of $\mathrm{P}$ release.

Dose adequacy also warrants mention. In the present experiment $P$ was supplied at $25 \mathrm{~kg} / \mathrm{ha}$, whereas Watt's (1966) response was to approximately $150 \mathrm{~kg} \mathrm{P} / \mathrm{ha}$. Pritchett (1968), with slash pine (Pinus elliottii Engelm.), found increasing response to at least $39 \mathrm{~kg} \mathrm{P} / \mathrm{ha}$. With Sitka spruce (Picea sitchensis [Bong.] Carr.) on peatlands in Scotland (Malcolm 1972) and Northern Ireland (Dickson 1971), $50 \mathrm{~kg} \mathrm{P} / \mathrm{ha}$ is a usual dose. There is the possibility then, that in the present experiment, had a greater amount been applied, the results might have been more clearcut.

\section{Acknowledgments}

The following persons made significant contributions to this work: Messrs. P. J. Ward, W. S. Moore and D. J. McKinnon of or formerly of Great Lakes Paper Co. Ltd., and Messrs. F. Hegyi and D. Ropke of the Canadian Forestry Service.

\section{References}

Anon. 1973. Canadian normals. 2. Precipitation 1941-1971. Can. Dep. Environ., Atmosph. Environ. Serv., Downsview, Ont. 330 p.

Anon. 1974. The system of soil classification for Canada. Can. Dep. Agric., Ottawa, Ont. Publ. 1455. 255 p.

Armson, K. A. 1967. Review of forest fertilization in Canada. Can. Dept. For. Rur. Dev., Ottawa, Ont. Publ. 1186. 175 p.

Chapman, L. J. and M. K. Thomas. 1968. The climate of northern Ontario. Can. Dep. Transp., Meteorol. Br. Climatol. Stud. 6. 58 p.

Dickson, D. A. 1971. The effect of form, rate and position of phosphatic fertilizers on growth and nutrient uptake of Sitka spruce on deep peat. Forestry 44:17-24.

Hegyi, F. 1974. What we found: Growth-response evaluation of fertilizer trials in jack pine-Dryden field trials. p. 33-38 in Proceedings of a Workshop on Forest Fertilization in Canada. Can. For. Serv., Sault Ste. Marie, Ont. For. Tech. Rep. No. 5.

Hills, G. A. 1959. A ready reference to the description of the land of Ontario and its productivity. Ont. Dep. Lands For. Prelimin. Rep. 142 p.

Honer, T. G. 1967. Standard volume tables and merchantable conversion factors for the commercial tree species of central and eastern Canada. Can. Dep. For. Rur. Dev., Ottawa, Ont. Inf. Rep. FMR-X-5. 153 p.

Malcolm, D. C. 1972. The aspects of tree nutrition. Forestry $26 ; 29-36$.

Nommik, H. and J. Thoren. 1971. Transformation of ${ }^{15} \mathrm{~N}$ labelled nitrite and nitrate in forest raw humus during anaerobic incubation, p. 369-382 in I.A.E.A. Symp. on Use of Isotopes and Radiation in Research in Soil-Plant Relationships including Forestry, Vienna.

Pritchett, W. L. 1968. Progress in the development of techniques and standards for soil and foliar diagnosis of phosphorus deficiency in slash pine. p. 81-87 in Anon. 1968. Forest Fertilization... theory and practice. Tenn. Val. Auth., Muscle Shoals, Ala.

Roberge, M. and Knowles, R. 1966. Ureolysis, immobilization and nitrification in black spruce (Picea mariana [Mill.] B.S.P.) humus. Soil Sci. Soc. Am. Proc. 30:201-204.

Rowe, J. S. 1972. Forest regions of Canada. Can. For. Serv. Ottawa. Publ. No. 1300. 172 p.

Van Nostrand, R. S. and N. D. Bhure. 1973. Growth response of black spruce to fertilization in Newfoundland. Can. For. Serv., St. John's, Nfld. Inf. Rep. N-X-95.

Watt, R. F. 1966. Growth of black spruce stands after fertilization treatments based on foliar analysis. Soc. Am. For. Proc. p. 85-88.

Watt, R. F. 1966. Growth of black spruce stands after phosphorus level related to site quality in a northern Minnesota spruce bog. Ecology 46:357-361.

Weetman, G. F. 1968. The nitrogen fertilization of three black spruce stands. Pulp Pap. Res. Inst. Can. Woodl. Rep. 6. $45 \mathrm{p}$.

Weetman, G. F. 1975. Ten-year growth response of black spruce to thinning and fertilization treatments. Can. J. For. Res. 5:302-309. 